\title{
Algae grown on dairy and municipal wastewater for simultaneous nutrient removal and lipid production for biofuel feedstock
}

\author{
I. Woertz ${ }^{1}$, A. Feffer ${ }^{2}$, T. Lundquist ${ }^{3}$, Y. Nelson ${ }^{4}$ \\ Civil and Environmental Engineering Department, California Polytechnic State University, \\ San Luis Obispo, CA 93407
}

\section{Abstract}

Algae grown on wastewater media are a potential source of low-cost lipids for production of liquid biofuels. This study investigated lipid productivity and nutrient removal by green algae grown during treatment of dairy farm and municipal wastewaters supplemented with $\mathrm{CO}_{2}$. Dairy wastewater was treated outdoors in bench-scale batch cultures. The lipid content of the volatile solids peaked at Day 6, during exponential growth, and declined thereafter. Peak lipid content ranged from 14-29\%, depending on wastewater concentration. Maximum lipid productivity also peaked at Day 6 of batch growth, with a volumetric productivity of 17 $\mathrm{mg} / \mathrm{day} / \mathrm{L}$ of reactor and an areal productivity of $2.8 \mathrm{~g} / \mathrm{m}^{2} /$ day, which would be equivalent to 11,000 L/ha/yr (1,200 gallons/acre/year) if sustained year-round. After 12 days, ammonium and orthophosphate removals were $96 \%$ and $>99 \%$, respectively. Municipal wastewater was treated in semi-continuous indoor cultures with 2-4 day hydraulic residence times (HRTs). Maximum lipid productivity for the municipal wastewater was $24 \mathrm{mg} /$ day/L, observed in the 3-day HRT cultures. Over 99\% removal of ammonium and orthophosphate was achieved. The results from both types of wastewater suggest that $\mathrm{CO}_{2}$-supplemented algae cultures can simultaneously remove dissolved nitrogen and phosphorus to low levels while generating a feedstock potentially useful for liquid biofuels production. 
Keywords: Biofuels, biodiesel, algae, lipids, algal polycultures, wastewater treatment, dairy waste, municipal, nutrient removal, carbon dioxide

1. Currently Research Engineer, Civil and Environmental Engineering Department, California Polytechnic State University, 1 Grand Ave., San Luis Obispo, CA 93407

2. Currently Project Coordinator, LifeWater International, Inc. 3563 Empleo St., Suite C, San Luis Obispo, CA 93401

3. Assistant Professor, Civil and Environmental Engineering Department, California Polytechnic State University, 1 Grand Ave., San Luis Obispo, CA 93407

4. Professor, Civil and Environmental Engineering Department, California Polytechnic State University, 1 Grand Ave., San Luis Obispo, CA 93407 


\section{Introduction}

Biofuels produced from plants have the potential to replace a significant fraction of our fossil fuel needs with a renewable alternative (Perlack et al. 2005). However, concern has grown that the use of food crops for production of ethanol, biodiesel or other renewable fuels will increase food prices while having little impact on greenhouse gas emissions (Fargione et al. 2008). Prior work, in particular the Aquatic Species Program sponsored by the US Department of Energy, suggested that algae are capable of producing oil suitable for conversion to biodiesel with an areal productivity 20-40 times that of oilseed crops, such as soy and canola (Sheehan et al. 1998). However, an economic study of such processes (Benemann and Oswald 1996) suggested that large-scale algae cultivation solely for biofuel production was not economical, and the authors re-emphasized the integration of biofuels production and wastewater treatment with $\mathrm{CO}_{2}$ supplementation, as first suggested by Oswald and Golueke (1960). In particular, assimilation of wastewater nutrients by algae followed by algae harvesting via sedimentation were considered potentially practical and economical approaches to biofuel production.

Use of algae for municipal wastewater treatment in ponds is well established (Oswald et al. 1953, Oswald 2003), and algae-based treatment of dairy and piggery waste also has been investigated (e.g., Craggs et al. 2004, Kebede-Westhead et al. 2006, Mulbry et al. 2008, An et al. 2003). Algae growth in wastewater treatment ponds contributes to treatment mainly through dissolved oxygen production and nutrient assimilation. However, the carbon:nitrogen and carbon:phosphorus ratios in domestic sewage (C:N 3.5:1; C:P 20:1) and dairy lagoon water (C:N 3:1; C:P 10:1) are low compared to typical ratios in rapidly-growing algae 
biomass (C:N 6:1; C:P 48:1) (Metcalf and Eddy 2006, USDA 1992, Oswald 1960). This dearth of carbon leads to limitations in algae production and incomplete assimilation of wastewater nutrients by algae. The experiments described in the present research overcame the carbon limitation of the wastewaters by addition of $\mathrm{CO}_{2}$ to the cultures. The effects of this addition on both algae growth and nutrient assimilation were measured. In future applications, $\mathrm{CO}_{2}$ could be supplied by the flue gas from power plants and other sources. A schematic of one envisioned process is shown in Figure 1.

$\mathrm{CO}_{2}$ supplementation of algae cultures to increase productivity has been studied for many years (Burlew 1953), as has the use of flue gas as a $\mathrm{CO}_{2}$ source for algae culture (Straka et al. 2000). $\mathrm{CO}_{2}$ supplementation to promote nutrient removal has also been studied briefly in outdoor ponds (Benemann et al. 1980). However, the production of lipids was not measured in these studies.

Lipid content for pure cultures of algae have been reported to range from $1 \%-85 \%$, and the lipids exhibit varying carbon chain lengths, degrees of unsaturation, and polarity (e.g., reviews in Chisti 2007, Metting 1996, and Enssani 1987). However, the lipid content and, more importantly, the lipid productivity of polycultures of algae, such as wastewater pond algae, have seldom, if ever, been reported. Further, lipid content, fatty acid profile, and biomass productivity depend on environmental conditions, culturing methods, and growth phase (Thompson 1996, Tsuzuki et al. 1990). In particular, nitrogen limitation increases lipid content in some species (Spoehr and Milner 1949, Leman 1997). However, nitrogen limitation decreases growth rate, which can lead to decreased overall lipid productivity 
(Shiffrin and Chisolm 1981). Benemann and Tillett (1987) investigated this problem, but maximizing lipid productivity remains an outstanding problem.

While a few studies have reported the lipid content of waste-grown algae cultures (e.g., 25\%, Enssani 1987), lipid productivities for waste-grown polycultures apparently have not been reported previously. The research presented herein was conducted to determine the lipid content and lipid productivity of microalgae grown for nutrient removal from two types of wastewater-dairy and municipal.

\section{Methods}

\section{Overview of Experiments}

Two sets of experiments were run in parallel to determine algae growth, nutrient removal, and lipid productivity in municipal wastewater and dairy wastewater. The municipal wastewater experiment monitored algae growth under semi-continuous operation for 18 days to study the effects of $\mathrm{CO}_{2}$ levels and hydraulic residence times on algae growth and nutrient removal. Control cultures with addition of air only (no $\left.\mathrm{CO}_{2}\right)$ were used to simulate the carbonlimitation typical of wastewater ponds and to differentiate the effect of $\mathrm{CO}_{2}$ addition on productivity. In the dairy wastewater experiment, lipid productivity and nutrient removal were monitored during 15 days of batch growth to study the effect of the growth cycle on lipid content. 


\section{Collection and pretreatment of wastewater}

For the municipal wastewater experiments, $60 \mathrm{~L}$ of primary clarifier effluent was collected at the San Luis Obispo, California, municipal wastewater treatment facility. The wastewater was mixed thoroughly and passed through screens with 196- $\mu$ m openings (commercial house paint filters). The screened wastewater was stored in 4-L HDPE containers at $-10^{\circ} \mathrm{C}$.

For the dairy wastewater experiments, free-stall barn flush water was collected from a storage pond at the 400-head Cal Poly Dairy in San Luis Obispo. In flush operations at this dairy, the flush water is passed through a bar screen and sand trap and then collected in a covered sump. The wastewater is then pumped over a wedge-wire inclined screen, which removes feed and other fine solids, before being discharged to the 0.5 -ha storage pond. Wastewater for the research was collected from the storage pond and then treated in an anaerobic digester before being used in algae growth experiments. The 130-L digester was unheated, unmixed and fed semi-continuously to achieve a 6-week hydraulic residence time.

\section{Municipal wastewater experimental procedures}

Eight 1-L Pyrex Roux bottles (Fisher Scientific) were used as algae growth reactors for the municipal wastewater experiments. Each bottle was placed vertically on a magnetic stirrer and mixed by a PTFE-coated $2.5-\mathrm{cm}$ magnetic stir bar spinning at approximately $300 \mathrm{rpm}$. The bottles were illuminated from two sides by a total of four 40-W full-spectrum fluorescent bulbs (Durotest Vitalite ${ }^{\circledR}$ ) operated on a $16 \mathrm{hr}: 8 \mathrm{hr}$ light:dark cycle. When on, the bulbs provided an average illuminance that totaled 4300 lux at the two faces of each bottle (Lutron 
LX-101 meter), which is equivalent to about $12 \mathrm{~W} / \mathrm{m}^{2}$ of photosynthetically active radiation (Li-Cor, 2008).

To provide gas exchange, each bottle was sparged with either air or a $\mathrm{CO}_{2}$-air mixture through a cylindrical polypropylene diffuser $36-\mathrm{mm}$ long and 9-mm in diameter. Gas was delivered to the diffusers through a manifold of 4-mm ID clear vinyl tubing with manual flow control valves. For bottles sparged with air- $\mathrm{CO}_{2}$ mixtures, gases were mixed by a Matheson Model 665 gas mixer that was connected to a 50-lb tank of $99.97 \% \mathrm{CO}_{2}$ and a Maxima Model A-805 2.5-psi aquarium air pump. The $\mathrm{CO}_{2}$ concentration in the blend was set to maintain $\mathrm{pH}$ between 7.0 and 8.0. For the Roux bottles that were sparged with air alone, the 4-mm tubing was connected to a $3-\mathrm{W}$ aquarium air pump (Profile 1500).

The culture volume in each Roux bottle was $800 \mathrm{~mL}$. Wastewater was introduced into the bottles with a daily draw-fill procedure at the end of the light period. Three daily hydraulic loading rates were tested $-200 \mathrm{~mL}, 267 \mathrm{~mL}$, and $400 \mathrm{~mL}$ of primary effluent - in order to achieve four-, three-, and two-day hydraulic residence times (HRTs), respectively. For the air- $\mathrm{CO}_{2}$ sparged treatments, each HRT was run in duplicate. For the air-only treatment, the 3day HRT was run in duplicate. Culture media temperature ranged from $23^{\circ} \mathrm{C}$ to $25^{\circ} \mathrm{C}$ and did not vary between the bottles more than $1.5^{\circ} \mathrm{C}$.

\section{Dairy wastewater experimental procedures}

For the dairy wastewater, algae were cultured outdoors in six 40-L rectangular glass aquarium tanks (Figure 2). The tanks were filled with $20 \mathrm{~L}$ of effluent from the anaerobic digester. To 
better simulate light conditions in ponds, sunlight was allowed to enter the tanks only through the top water surface by masking the tank walls up to the waterline with black tape. A Plexiglas ${ }^{\circledR}$ cover excluded rainfall, but a gap was provided between the cover and the tanks for ventilation.

In preliminary experiments with undiluted dairy wastewater algal growth was poor, presumably due to the high opacity of the wastewater. Therefore, the subsequent experiments reported here, used $10 \%$ and $25 \%$ wastewater diluted with tap water. Each experimental treatment was run in triplicate with air-sparging at $1.5 \mathrm{~L} / \mathrm{min}$ for mixing, and separate, simultaneous $\mathrm{CO}_{2}$ sparging at approximately $0.015 \mathrm{~L} / \mathrm{min}$, which controlled culture $\mathrm{pH}$.

The experiment was run during March 2007 when the average daily solar radiation was 203 $\mathrm{W} / \mathrm{m}^{2}$ (California Irrigation Management Information System Station \#52). The average water temperature, measured daily at 3:00 PM, was $30.6^{\circ} \mathrm{C}$. Water samples were collected between 3:00 and 3:30 PM.

\section{Inoculation}

Algae inoculum was collected from local ponds treating municipal or winery wastewater and from a creek. The inoculum samples contained a wide-ranging mixture of green algae and diatoms, which were identified by cell morphology using phase-contrast microscopy with reference to Prescott et al. (1978). Prominent genera included Actinastrum, Scenedesmus, Chlorella, Spirogyra, Nitzschia, Micractinium, Golenkinia, Chlorococcum, Closterium, Euglena, and two unidentified species. The municipal culture inoculum contained $625 \mathrm{mg} / \mathrm{L}$ 
volatile suspended solids (VSS) and was added to the wastewater media in a $2 \%(\mathrm{v} / \mathrm{v})$ ratio. For the dairy cultures, the inoculum concentration was $500 \mathrm{mg} / \mathrm{L}$ VSS, added at a $10 \%(\mathrm{v} / \mathrm{v})$ ratio.

\section{Water Quality Analyses and Lipid Extraction}

VSS concentrations were determined gravimetrically according Standard Methods (APHA, 2005). Temperature and $\mathrm{pH}$ were monitored to characterize growth conditions. Nutrient removal was evaluated by analyzing for nitrite, nitrate, and orthophosphate using a Dionex DX 120 ion chromatograph with an AG9-HC IonPac ${ }^{\circledR}$ Guard Column, AS9-HC 4-mm IonPac ${ }^{\circledR}$ IC column, DS4-1 Detection Stabilizer and an AS40 Automated Sampler. Total ammonia nitrogen $\left(\mathrm{NH}_{3}+\mathrm{NH}_{4}{ }^{+}-\mathrm{N}\right)$ concentrations were determined using the AmmoniaSelective Electrode Method (APHA 4500- $\mathrm{NH}_{3}$ D). Organic nitrogen was determined using the Macro-Kjeldahl method (APHA Method $4500-\mathrm{N}_{\text {org }}$ ).

To complete a nitrogen balance for the Roux bottle experiments, it was necessary to quantify the volatilization of ammonia. This quantity was determined by passing the sparged gas through a boric acid solution. This procedure was conducted for one Roux bottle of each duplicate. A two-hole stopper with 4-mm tubing allowed sparging gas in and directed sparged gas out and into the boric acid solution through a polypropylene diffuser. The diffuser was submersed $12 \mathrm{~cm}$ in a graduated cylinder under 100-200 $\mathrm{mL}$ of boric acid indicating solution (APHA $4500-\mathrm{NH}_{3}$ C. 3.b.). At the end of a mass balance period, DI water was added to the graduated cylinder to compensate for evaporation. This solution was then 
titrated back to its original $\mathrm{pH}$, and its ammonia concentration was calculated according to APHA 4500- $\mathrm{NH}_{3} \mathrm{C}$.

The lipid content of the VSS was analyzed gravimetrically by a procedure adapted from Bligh and Dyer (1959) by Benemann and Tillett (1987). The method consisted of solvent-based extraction to isolate both polar and nonpolar lipids from cell biomass and water. The VSS of each sample was measured to determine the concentration of algal biomass in the wastewater effluent. A 200-mL aliquot of the same sample was centrifuged in a PTFE tube to form an algae pellet for lipid extraction. After decanting, the pellet was re-suspended in $4 \mathrm{~mL}$ of DI water and frozen until extraction. For extraction, the samples were thawed, and $5 \mathrm{~mL}$ of chloroform and $10 \mathrm{~mL}$ of methanol were added. The samples were then sonicated continuously in the centrifuge tube for $1 \mathrm{~min}$. (Branson Sonifier 250 with a Model \#102 tip). The samples were then placed on a shaker table overnight. The next day an additional $5 \mathrm{~mL}$ of chloroform and $5 \mathrm{~mL}$ of DI water were added to make the final ratio of chloroform:methanol:water 10:10:9. The samples were then vortexed for $30 \mathrm{sec}$. After the samples had been homogenized, they were centrifuged at $7000 \mathrm{rpm}$ for $4 \mathrm{~min}$. The lipids were soluble in the chloroform, which formed a dense layer at the bottom of the centrifuge tube. The remaining cell debris created a middle layer, while the methanol and water created a top layer. The lipid-chloroform layer was removed with a pipette and filtered through a 0.2$\mu \mathrm{m}$ nylon syringe filter. The filtrate was deposited into a tared aluminum tray. The tray was then placed into a desiccator flushed with nitrogen to allow the chloroform to evaporate. A second extraction was performed by adding an additional $10 \mathrm{~mL}$ of chloroform to the centrifuge tube, and the mixture was again vortexed and centrifuged. This second extraction 
was placed into a separate tared tray and evaporated under nitrogen. The trays were then dried at $105^{\circ} \mathrm{C}$ for one hr. After cooling in a desiccator, the trays were weighed to the nearest $0.01 \mathrm{mg}$. Adding the weights of the two extractions from each sample gave the total lipid weight.

\section{Results and Discussion}

\section{Influent wastewater characteristics}

The municipal primary wastewater characteristics, as well as the initial conditions in the dairy wastewater bioreactors immediately after inoculation are reported in Table 1. After dilution, the $25 \%$ dairy wastewater had ammonium and orthophosphate concentrations similar to the undiluted municipal wastewater.

\section{Culture conditions}

The laboratory municipal wastewater cultures were grown under steady conditions as described in the Methods section. However, the outdoor dairy wastewater cultures experienced widely varying conditions both daily and over the course of the experiments (Table 2). The average 24-hr insolation ranged from $50-252 \mathrm{~W} / \mathrm{m}^{2}$. Due to manual adjustment of $\mathrm{CO}_{2}$ flow, $\mathrm{pH}$ ranged from 6.5-8.9. The water temperatures in all the tanks were similar and reached as high as $37^{\circ} \mathrm{C}$ (Table 2). 


\section{Algal and lipid productivity}

The semi-continuous-flow experiments with municipal wastewater reached nearly steadystate biomass concentrations after 11 days of operation, although VSS was higher on the $18^{\text {th }}$ day, when lipid samples were taken (Figure 3). For the 3-d HRT cultures, sparging with $\mathrm{CO}_{2}$ more than doubled the VSS concentration compared to sparging with air. For the treatments with $\mathrm{CO}_{2}$ sparging, biomass production was similar for the 3- and 4-day HRTs, with steadystate VSS concentrations of 700-800 mg/L. In contrast, the steady-state VSS concentration for the $\mathrm{CO}_{2}$-sparged 2-d HRT treatment was only $300 \mathrm{mg} / \mathrm{L}$. The municipal wastewater cultures were dominated by algae in the Chlorella, Micractinium, and Actinastrum genera.

The lipid contents of the algae from the municipal wastewater experiments ranged from 4.9$11.3 \%$ of VSS by weight (Table 3). Despite the relatively low lipid contents observed, short residence times and high biomass production rates resulted in lipid productivities ranging from $9.7 \mathrm{mg} / \mathrm{L} /$ day (air-sparged) to $24 \mathrm{mg} / \mathrm{L} /$ day $\left(\mathrm{CO}_{2}\right.$-sparged, 3-d HRT).

Lipid production using dairy wastewater was measured in batch experiments with two different dilutions of wastewater (10\% and $25 \%)$. Biomass concentrations increased to maximum values of $500 \mathrm{mg} / \mathrm{L}$ VSS at Day 6 for the $10 \%$ dilution (Figure 4) and $900 \mathrm{mg} / \mathrm{L}$ VSS at Day 13 for the $25 \%$ dilution (Figure 5). The higher biomass production for the $25 \%$ dilution was likely due to the higher nutrient concentrations (Table 1). The dairy wastewater cultures were dominated by Scenedesmus, followed by Micractinium, Chlorella, and Actinastrum. These were the same genera that dominated in the municipal wastewater cultures, except that Scenedesmus was absent in the municipal cultures. 
For both dairy wastewater dilutions, the highest lipid content was observed during the exponential growth phase, and it declined thereafter (Figures 4 and 5). The total lipid content of biomass from the $10 \%$ dilution ranged from $8-14 \%$, and that of the $25 \%$ dilution ranged from $10-29 \%$ by weight. In comparison, total lipid content of pure Scenedesmus and Chlorella cultures has been reported to range from 12-45\% (Thompson 1996).

For the dairy wastewater experiments, the maximum lipid production rate was $17 \mathrm{mg} / \mathrm{L} / \mathrm{day}$ on a volumetric basis or $2.8 \mathrm{~g} / \mathrm{m}^{2} /$ day on an area basis, achieved by Day 6 for the $25 \%$ dilution. In comparison, previous research with open-surface systems growing pure cultures have shown somewhat higher production rates ranging from 4-7.9 $\mathrm{g} / \mathrm{m}^{2} /$ day (Table 4; Laws 1984, Thomas 1984, and Brown 1990).

In both the batch and semi-continuous experiments, peak lipid content was associated with high biomass growth rates. For the dairy wastewater experiments, the highest lipid content and productivity was achieved during exponential growth for both the $10 \%$ and $25 \%$ dilution experiments, rather than during later phases when nutrient concentrations were low (Figures 4, 5 and 7). For the indoor municipal wastewater experiment, the highest lipid content (11\%) was observed at the shortest HRT (2-day). In these semi-continuous-flow experiments, the shorter retention time corresponded to more rapid biomass growth and greater lipid productivity. Thus high lipid production was associated with rapid growth for both batch dairy and semi-continuous municipal wastewater experiments. Roessler (1990) has discussed similar results of increased lipid content in the exponential growth phase of microalgae and 
theorized that at lower biomass concentrations with less self-shading, algae biosynthesize lipid storage products as a means of capturing excess light energy. In contrast, others have found higher lipid content in cultures that were nutrient limited (Leman 1997, Spoehr and Milner 1949).

The maximum observed lipid productivity of the dairy waste reactors $\left(2.8 \mathrm{~g} / \mathrm{m}^{2} /\right.$ day $)$ corresponds to about $11,000 \mathrm{~L} / \mathrm{ha} / \mathrm{yr}$ (1,200 gallons/acre/year). Without improvements, productivity in full-scale high-rate algae ponds is expected to be lower due to factors such as winter insolation and temperature, predation, maintenance downtime, and shifts in algal strains. For example, assuming 300 days/yr of operation, the productivity would be reduced to $9,000 \mathrm{~L} / \mathrm{ha} / \mathrm{yr}$ (960 gallons/acre/year). An additional uncertainty in scale-up estimates stems from the difference in operational modes for the dairy wastewater experiments (batch) and typical high-rate pond wastewater treatment (continuous). Theoretically, the maximum growth rate achieved in batch culture could also be achieved in continuous flow culture (Gualtieri and Barsanti 2005). Of course, the actual productivity for a full-scale system will depend on local environmental conditions, cultivation parameters, dominant algal strains, etc. Furthermore, the suitability of the algal lipids for fuel production will depend on the lipid characteristics (e.g., polarity, saturation level, and chain length) and the ease of extraction.

Much higher algal lipid productivities have been envisioned (e.g., 42,600-136,900 L/ha/yr, Chisti 2007) than observed in this study. However, even this study's oil production estimate of $9,000 \mathrm{~L} / \mathrm{ha} / \mathrm{yr}$ is 18 -times greater than the $490 \mathrm{~L} / \mathrm{ha} / \mathrm{yr}$ reported for soybean oil production (USDA 2005). 


\section{Nutrient removal}

For the municipal wastewater, over $99 \%$ ammonium and orthophosphate removal was achieved for $\mathrm{CO}_{2}$-sparged treatments with both 3- and 4-d HRT (Table 5). To determine the fate of the removed ammonium and to validate the results, a nitrogen balance was calculated on four occasions over ten days of operation. The results were similar on all four days, and Figure 6 shows the balance for Day 18. The average recovery achieved was $96 \%$ with a standard deviation of $8.7 \%$. Ammonium was the main form of nitrogen in the influent wastewater, and after algal growth, organic nitrogen was predominant (Figure 6). Ammonia volatilization was minor, the greatest amount being $<1 \mathrm{mg} /$ bottle/day from the air-sparged treatment, which accounts for $<7 \%$ of the influent total nitrogen. Since this treatment developed the highest $\mathrm{pH}$ (10.3) due to lack of $\mathrm{CO}_{2}$ sparging, it was the most prone to ammonia volatilization. The nitrite observed in the 2-day HRT effluent (Figure 6) indicates incomplete nitrification of ammonia for this short retention time.

Removal of ammonium and orthophosphate from the batch dairy wastewater was $96 \%$ and $>99 \%$ respectively by Day 15 (Table 6). For the $25 \%$ dilution experiment, initial concentrations of total ammonia nitrogen $\left(\mathrm{NH}_{\mathrm{x}}-\mathrm{N}\right)$ were $30 \mathrm{mg} / \mathrm{L}$ and were reduced to $<5$ $\mathrm{mg} / \mathrm{L}$ in 6 days (Figure 7). The initial orthophosphate phosphorus concentration of $2.6 \mathrm{mg} / \mathrm{L}$ was reduced to $0.6 \mathrm{mg} / \mathrm{L}$ in 9 days and completely removed by Day 12 . Nitrate concentrations were consistently below $0.3 \mathrm{mg} / \mathrm{L}$ for both conditions, and final nitrate concentrations were below the detection limit of $0.02 \mathrm{mg} / \mathrm{L} \mathrm{NO}_{3}{ }^{-} \mathrm{N}$. Similar results were 
observed with the $10 \%$ dairy wastewater dilution. Nitrite showed a slight increase at Day 6 up to $0.5 \mathrm{mg} / \mathrm{L} \mathrm{NO}_{2}-\mathrm{N}$, indicating some nitrification. Similar or higher ammonium removal efficiencies were observed by other researchers for algae-based treatment (Table 7).

\section{Conclusions}

This research provided a proof-of-concept for a wastewater treatment process that combines nutrient removal and algal lipid production for potential use as a biofuel feedstock. $\mathrm{CO}_{2}$ supplementation was used to accelerate treatment and growth in both outdoor and indoor mixed-species cultures. Ammonium and orthophosphate removals were nearly complete for both municipal wastewater and diluted dairy wastewater. This study also contributed data on both the lipid content and lipid productivity of wastewater-grown algae, a rarely addressed topic. Lipid content ranged from $4.9 \%-29 \%$, and lipid productivity reached $2.8 \mathrm{~g} / \mathrm{m}^{2} / \mathrm{d}$. While this lipid productivity is many times higher than that of terrestrial oil plants, higher productivity is a goal of continuing research. In addition, the suitability of the lipids for fuel production by transesterification and other means needs to be determined. Overall, the wasteto-biofuel approach of this study avoids many of the cost and food competition issues of other biofuel feedstocks while providing a valuable wastewater treatment service. 


\section{Acknowledgments}

Funding was provided by a US Environmental Protection Agency "People, Prosperity, and the Planet” grant, as well as a US Department of Energy Small Business Innovation Research grant to MicroBio Engineering. Lundquist was supported in part by the U.S. Office of Naval Research via the California Central Coast Research Partnership. The authors are grateful for consultation provided by Dr. John Benemann. 


\section{References}

An, J.Y., Sim, S.J., Lee, J.S., Kim, B. (2003). "Hydrocarbon production from secondary treated piggery wastewater by the green alga Botryococcus braunii." Journal of Applied Phycology, 15, 185-191.

APHA (2005). Standard Methods for the Examination of Water and Wastewater. American Public Health Association, American Water Works Association, and the Water Environment Federation.

Benemann, J., and Tillett, D. (1987). Effects of Fluctuating Environments on the Selection of High Yielding Microalgae. Final Report to the Solar Energy Research Institute, February 27, 1987.

Benemann, J.R., Koopman, B.L., Weissman, J.C., Eisenberg, D.M. and. Goebel, R. (1980). "Development of Microalgae Harvesting and High Rate Pond Technologies in California." In Algae Biomass: Production and Use, G. Shelef and C.J. Soeder (editors), Elsvier North Holland Press, Amsterdam, 457-496.

Benemann, J., Goebel, P., Weissman, J., and Augenstein, D. (1982). Microalgae as a Source of Liquid Fuels. Final technical report. Office of Energy Research, US Department of Energy. 
Benemann, J.R., Weissman, J.C., Eisenberg, D.M., Koopman, B.L., Goebel, R.P., Caskey, P.S. , Thomson, R.D., and Oswald, W.J. (1978). An Integrated System for the Conversion of Solar Energy with Sewage Grown Microalgae. Final Report, US Department of Energy, Contract D(04-3)-34, 272.

Benemann, J.R., and Oswald, W.J. (1996). Systems and Economic Analysis of Microalgae Ponds for Conversion of $\mathrm{CO}_{2}$ to Biomass. Final Report to the US Department of Energy Pittsburgh Energy Technology Center, Grant No. DE-FG22-03PC93204.

Bligh, E. and Dyer, W. (1959). "A rapid method for total lipid extraction and purification." Canadian Journal of Biochemical Physiology, 37, 911-917.

Weissman, J.C., Tillet, D., (1990). "Design and Operation of an Outdoor microalgae test facility: Large scale system results." In: Aquatic Species Project Report FY 1989-90, (Brown, L. M., and Sprague, S., ed.), NREL/TP-232-4174 DE92001207.

Craggs, R.J., Sukias, J.P., Tanner, C.T., and Davies-Colley, R.J. (2004). “Advanced pond system for dairy-farm effluent treatment." New Zealand Journal of Agricultural Research, $47,449-460$.

Chisti, Y. (2007). “Biodiesel from Microalgae.” Biotechnology Advances, 25, 294-306. 
Doucha, J., Straka, F., and Lívanský, K. (2005). "Utilization of flue gas for cultivation of microalgae (Chlorella sp.) in an outdoor open thin-layer photobioreactor." Journal of Applied Phycology, 17, 403-412.

Enssani, E. (1987). Fundamental Parameters in Extraction of Lipids from Wastewater-grown Microalgal Biomass. Ph.D. dissertation, Department of Civil Engineering, University of California, Berkeley, 194.

Fargione, J., Hill, J., Tilman, D., Polasky, S., Hawthorne, P. (2008). "Land clearing and the biofuel carbon debt." Science, 319, 1235-1238.

Golueke, C.G., Oswald, W.J., and Gotaas, H.B. (1957). “Anaerobic digestion of algae.” Applied Microbiology, 5(1), 47-55.

Green, F.B., Lundquist, T.J., and Oswald, W.J. (1995). "Energetics of advanced integrated wastewater pond systems.” Water Science Technology, 31(12), 9-20.

Gualtieri, P. and Barsanti, L. (2005). Algae: Biochemistry, Physiology, Ecology, and Biotechnology, CRC Press, 239.

Kebede-Westhead, E., Pizarro, C., and Mulbry, W. (2006). "Treatment of swine manure effluent using freshwater algae: production, nutrient recovery, and elemental composition of algal biomass at four effluent loading rates." Journal of Applied Phycology, 18(1), 41. 
Laws, E. (1984). Research and Development of Shallow Algal Mass Culture Systems for the Production of Oils. Report for the Solar Energy Research Institute, Subcontract No. XK-303136.

Leman, J. (1997). “Oleaginous microorganisms: an assessment of the potential." Advanced Applied Microbiology, 43, 195-243.

Li-Cor (2008). Principles of Radiation Measurement. v1.0 - LI-COR (11/2008). Li-Cor, Inc., Lincoln, Nebraska, pp. 10.

Lincoln, E.P., Wilkie, A.C., and French, B.T. (1996). "Cyanobacterial process for renovating dairy wastewater." Biomass and Bioenergy, 10(1), 63-68.

Matinez, M.E., Sanchez, S., Jimenez, J.M. El Yousfi, F., and Munoz, L. (2000). 'Nitrogen and phosphorus removal from urban wastewater by the microalga Scenedesmus obliquus." Bioresource Technology, 73, 263-272.

Metting, F.B. (1996). “Biodiversity and application of microalgae.” Journal of Industrial Microbiology, 17, 477-489.

Mulbry, W., Kondrad, S., and Buyer, J. (2008). "Treatment of dairy and swine manure effluents using freshwater algae: fatty acid content and composition of algal biomass at 
different manure loading rates." Journal of Applied Phycology, DOI 10.1007/s10811-0089314-8.

Oswald, W. J. (1960). "Fundamental factors in stabilization pond design.” Proc. 3rd Conference Biological Waste Treatment, Manhattan College, New York

Oswald, W.J. (2003). “My sixty years in applied algology.” Journal of Applied Phycology, $15,99-106$.

Oswald, W.J., Gotaas, H.B., Ludwig, H.F., and Lynch, V. (1953). “Algae symbiosis in oxidation ponds: photosynthetic oxygenation." Sewage and Industrial Wastes, 25(6), 692705.

Oswald, W.J. and C.G. Golueke (1960). "Biological transformation of solar energy." In: Advances in Applied Microbiology (W.W. Umbreit, ed.), Vol. 2, Academic Press, New York, pp. $223-262$.

Perlack, R.D., Wright, L.L., Turhollow, A.F., Graham, R.L., Stokes, B.J. and Erbach, D.C. (2005). Biomass as Feedstock for a Bioenergy and Bioproducts Industry: The Technical Feasibility of a Billion-Ton Annual Supply. DOE/GO-102005-2135, Oak Ridge National Laboratory, Oak Ridge, TN. 
Presscott, G., Bamrick, J., Cawley, E., Jaques, W. (1978). How to Know the Freshwater Algae. W.C. Brown Co., Dubuque, Iowa, 304.

Roessler, P. (1990). "Environmental control of glycerolipid metabolism in microalgae: commercial implications and future research directions." Journal of Phycology, 26, 393-399.

Sheehan, J., Dunahay, T., Benemann, J., and Roessler, P. (1998). A Look Back at the U.S. Department of Energy's Aquatic Species Program-Biodiesel from Algae. National Renewable Energy Laboratory, Golden, Colorado.

Shifrin, N., and Chisholm, S. (1981). "Phytoplankton lipids: interspecific differences and effects of nitrate, silicate and light-dark cycles." Journal of Phycology, 17, 374-384.

Spoehr, H.A. and Milner, H.W. (1949). "The chemical composition of Chlorella: effect of environmental conditions." Plant Physiology, 24, 120.

Straka, F., Doucha, J., and Livansky, K. (2000). "Flue-gas $\mathrm{CO}_{2}$ as a source of carbon in closed cycle with solar culture of microalgae." In Book of Abstracts, $4^{\text {th }}$ European Workshop on Biotechnology of Microalgae, May 2000, Bergholz-Rehbrucke, Germany, 29-30.

Thompson, G.A. (1996). "Lipids and membrane function in green algae.” Biochemica et Biophysica, 1306, 17-45. 
Tsuzuki, M., Ohnuma, E., Sato, N., Takaku, T., and Kayguchi., A. (1990). "Effects of $\mathrm{CO}_{2}$ concentration during growth on fatty acid composition in microalgae." Plant Physiology, 93, 851-856.

USDA (2005). Agricultural Statistics 2005. National Agricultural Statistics Service, United States Government Printing Office, Washington, D.C.

USDA (1992). Agricultural Waste Management Field Handbook, Chapter 4: Agricultural Waste Characteristics.” United States Department of Agriculture, Soil Conservation Service.

Weissman, J.C., and Goebel, R.P. (1987). Design and analysis of microalgal open pond systems for the purpose of producing fuels. Subcontract report Solar Energy Research Institute, Golden, Colorado. 


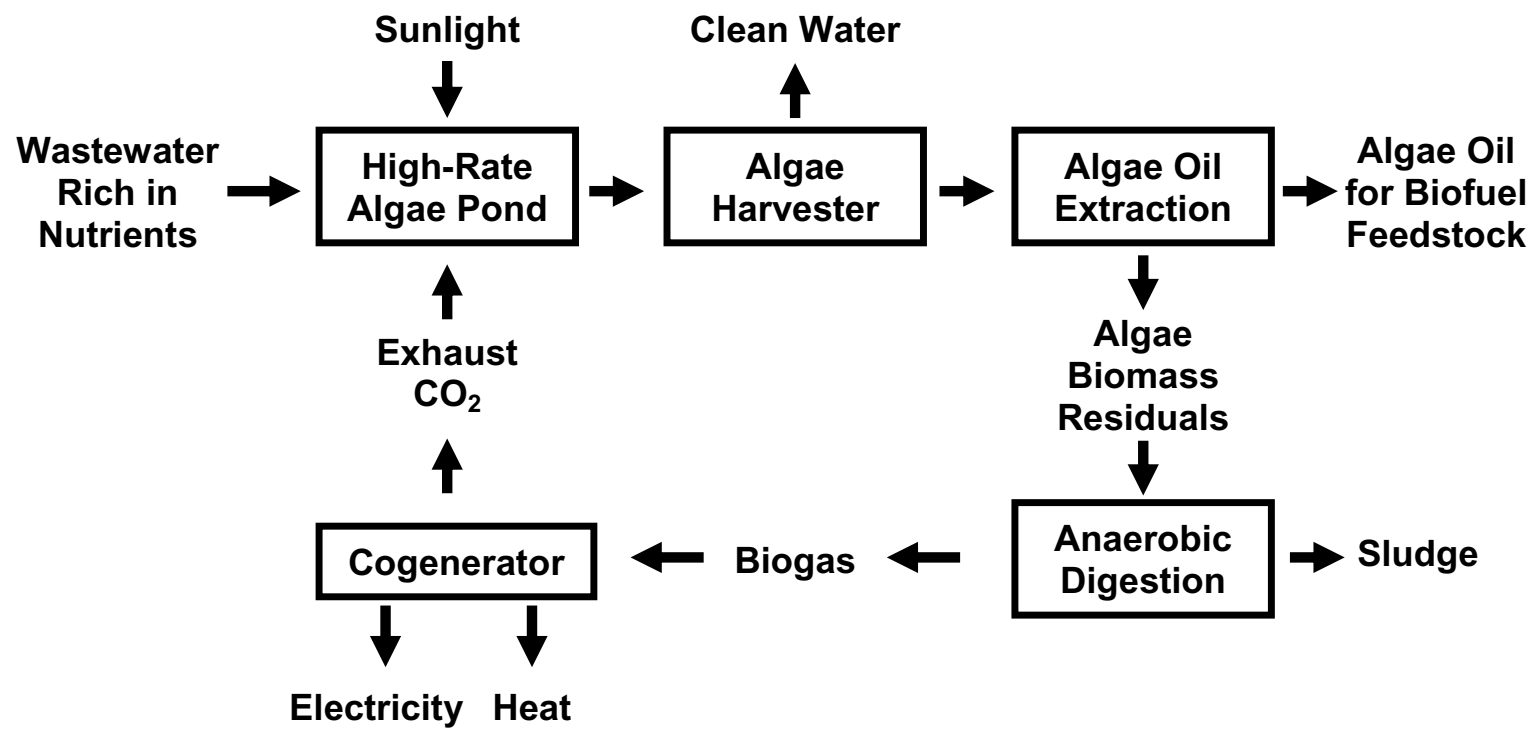

Figure 1: Simplified process flow diagram envisioned for algae wastewater treatment and liquid biofuel production. 


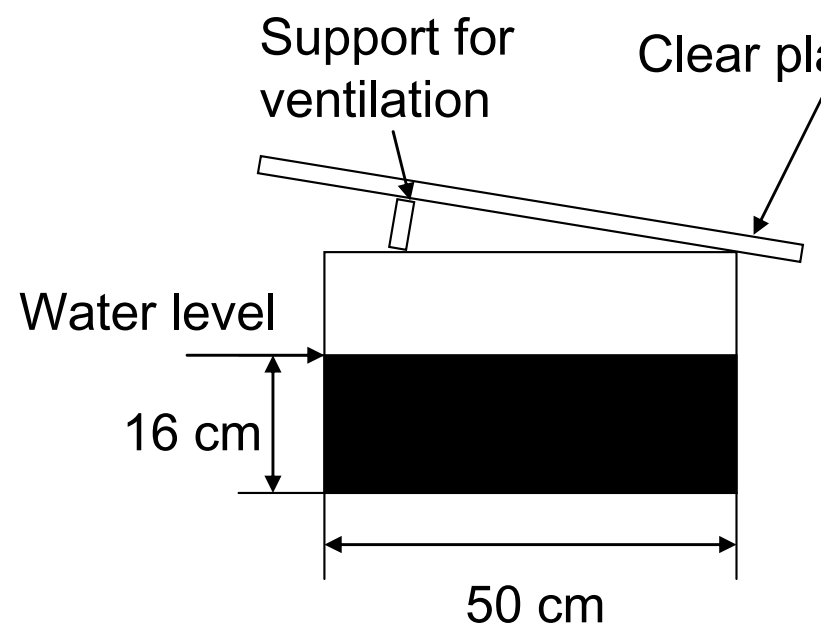

(Side view) astic cover

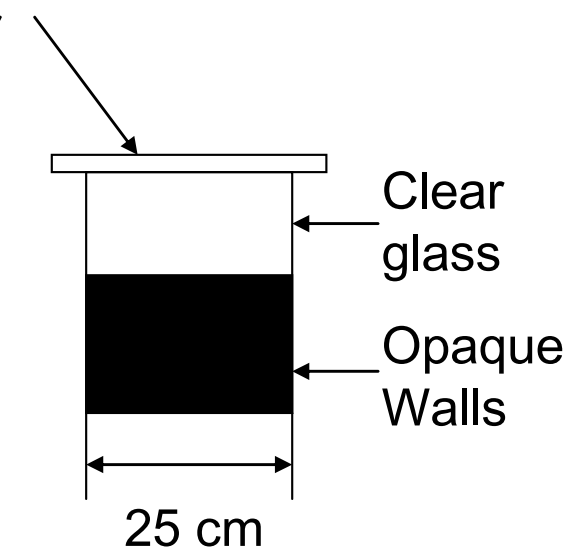

(Front view)

Figure 2: Outdoor algae growth tanks for batch experiments with dairy wastewater. 


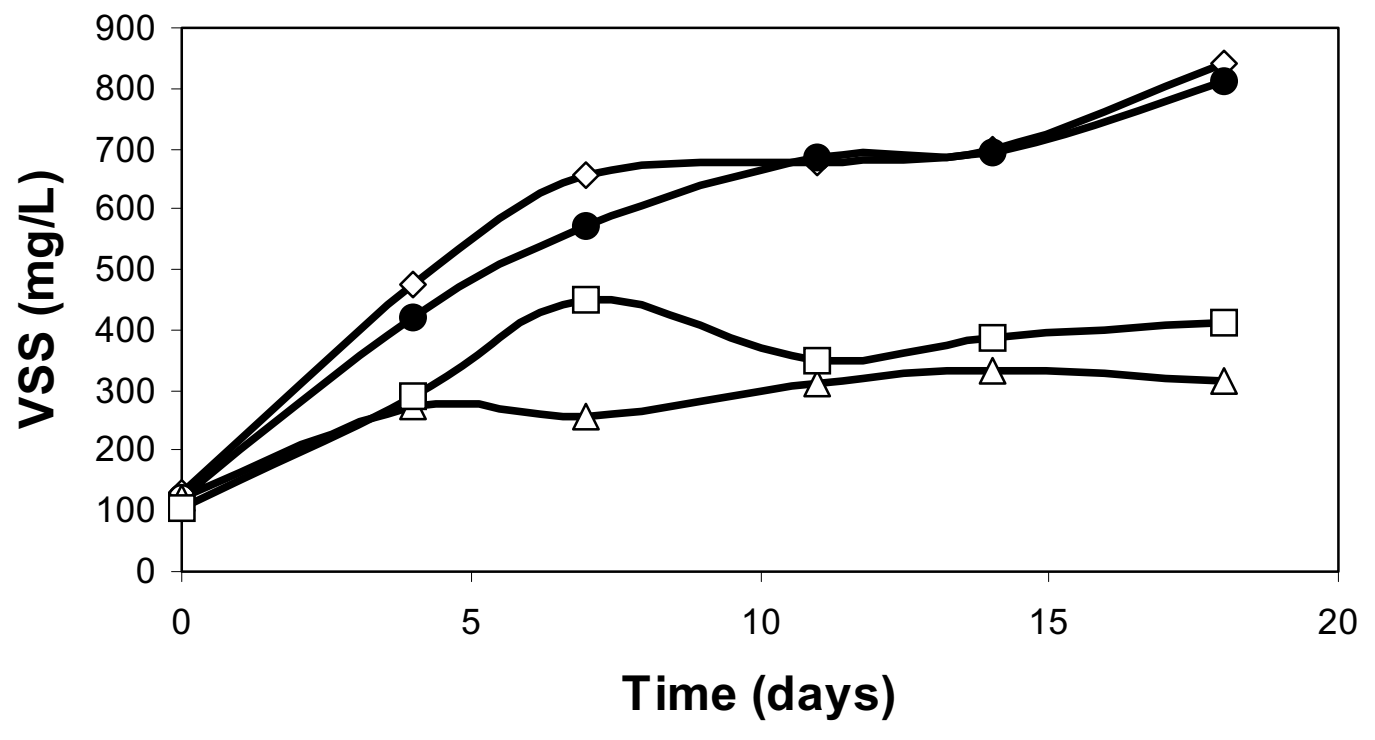

$\prec$ 4-Day HRT CO2 -3 -Day HRT CO2

$\rightarrow$ 3-Day HRT Air $\quad-\square-2-D a y$ HRT CO2

Figure 3: Biomass concentrations during semi-continuous flow treatment of municipal wastewater (mean of duplicates). 


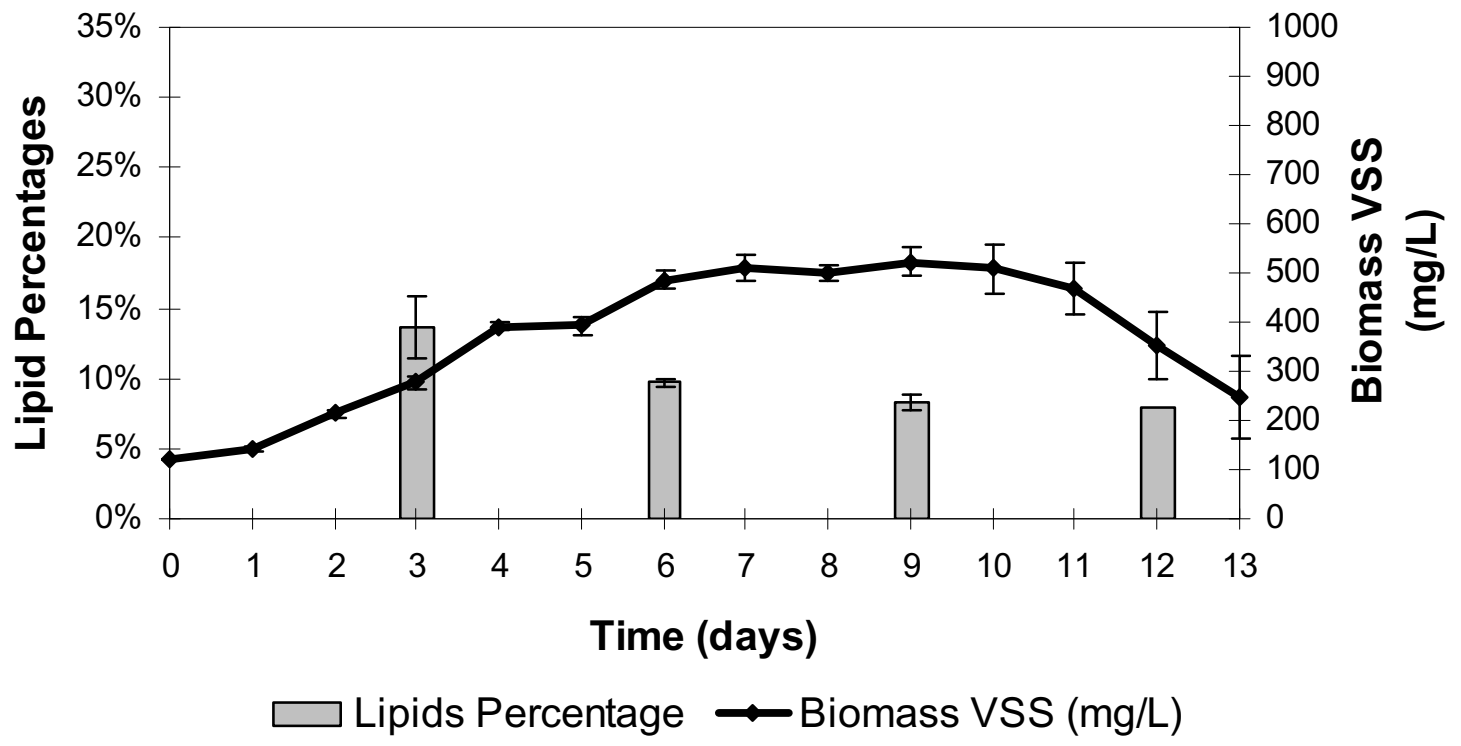

Figure 4: Biomass concentration and cell lipid content during batch algae growth on $10 \%$ dairy wastewater (mean of triplicates). 


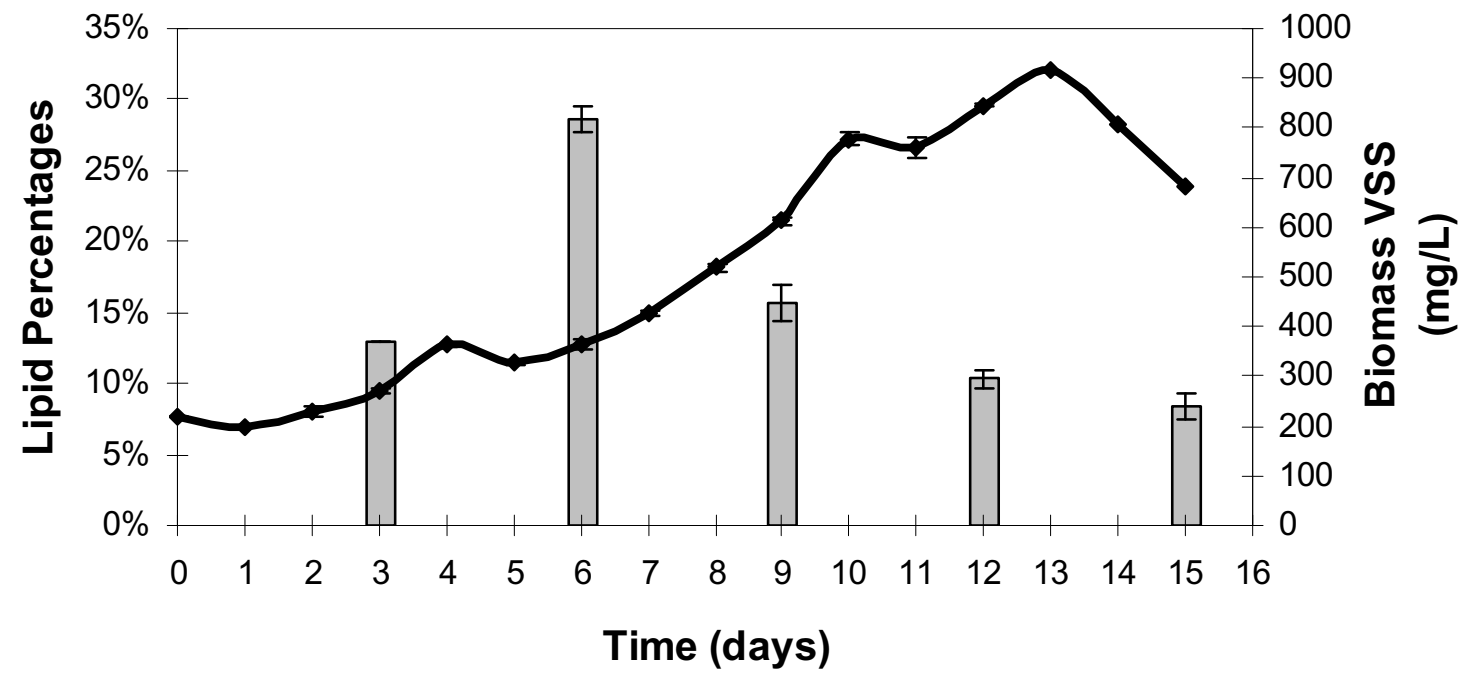

$\square$ Lipids Percentage $\rightarrow$ Biomass VSS (mg/L)

Figure 5: Biomass concentration and cell lipid content during batch algae growth on $25 \%$ dairy wastewater (mean of triplicates). 


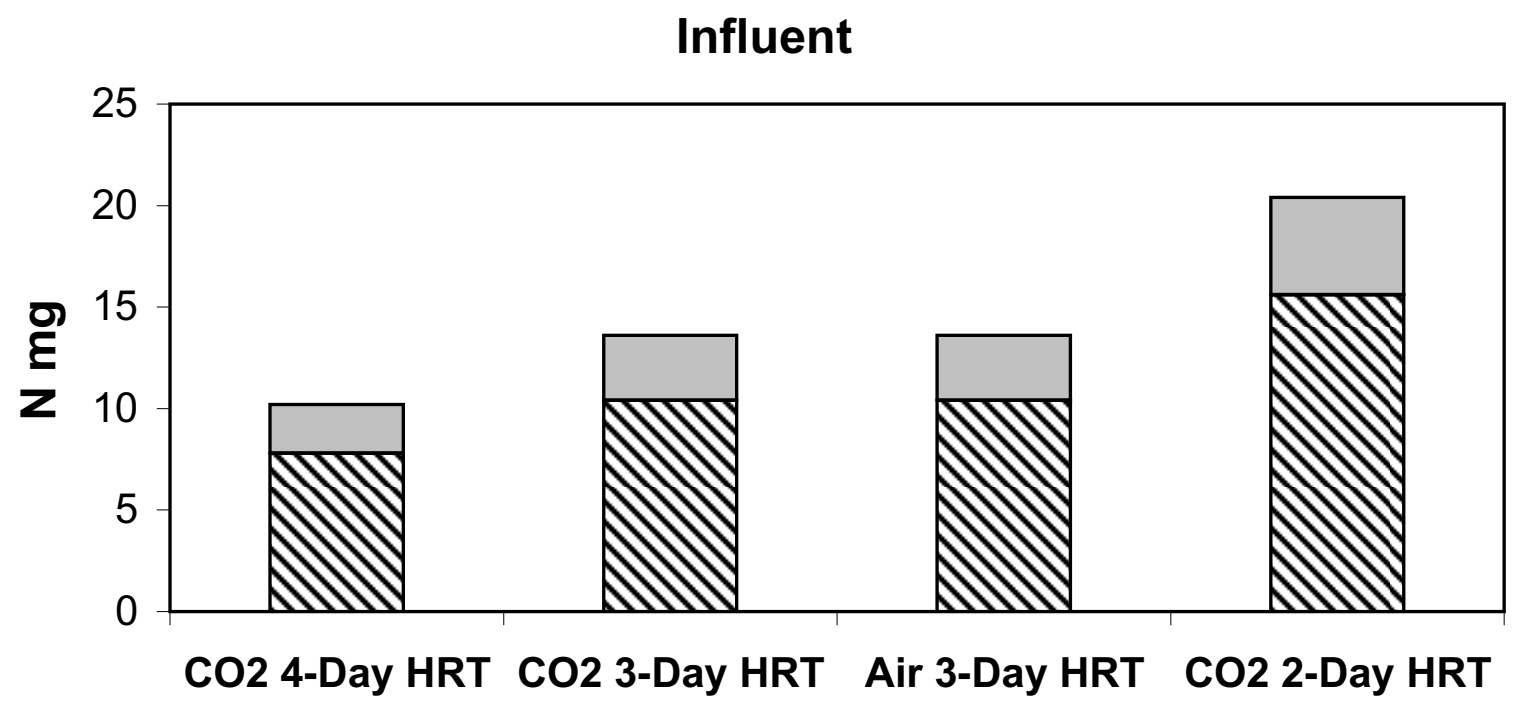

\$Ammonium-N $\square$ Nitrite-N $\square$ Nitrate-N $\square$ Organic N

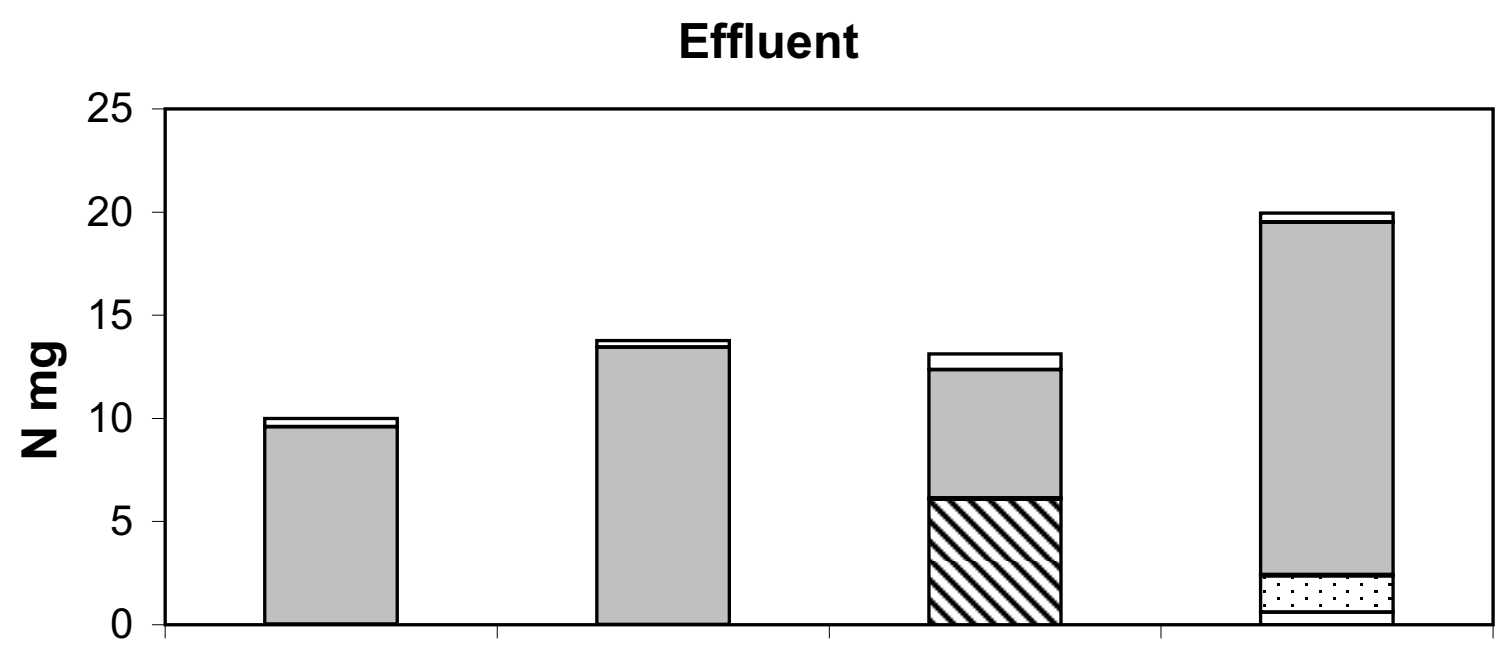

CO2 4-Day HRT CO2 3-Day HRT Air 3-Day HRT CO2 2-Day HRT

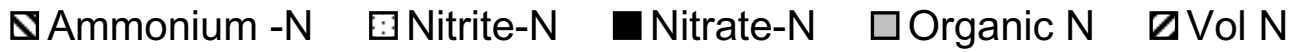

Figure 6: Nitrogen balance for municipal wastewater cultures on Day 18 (means of duplicates). "Vol $\mathrm{N}$ " is volatilized nitrogen captured in a boric acid solution. 


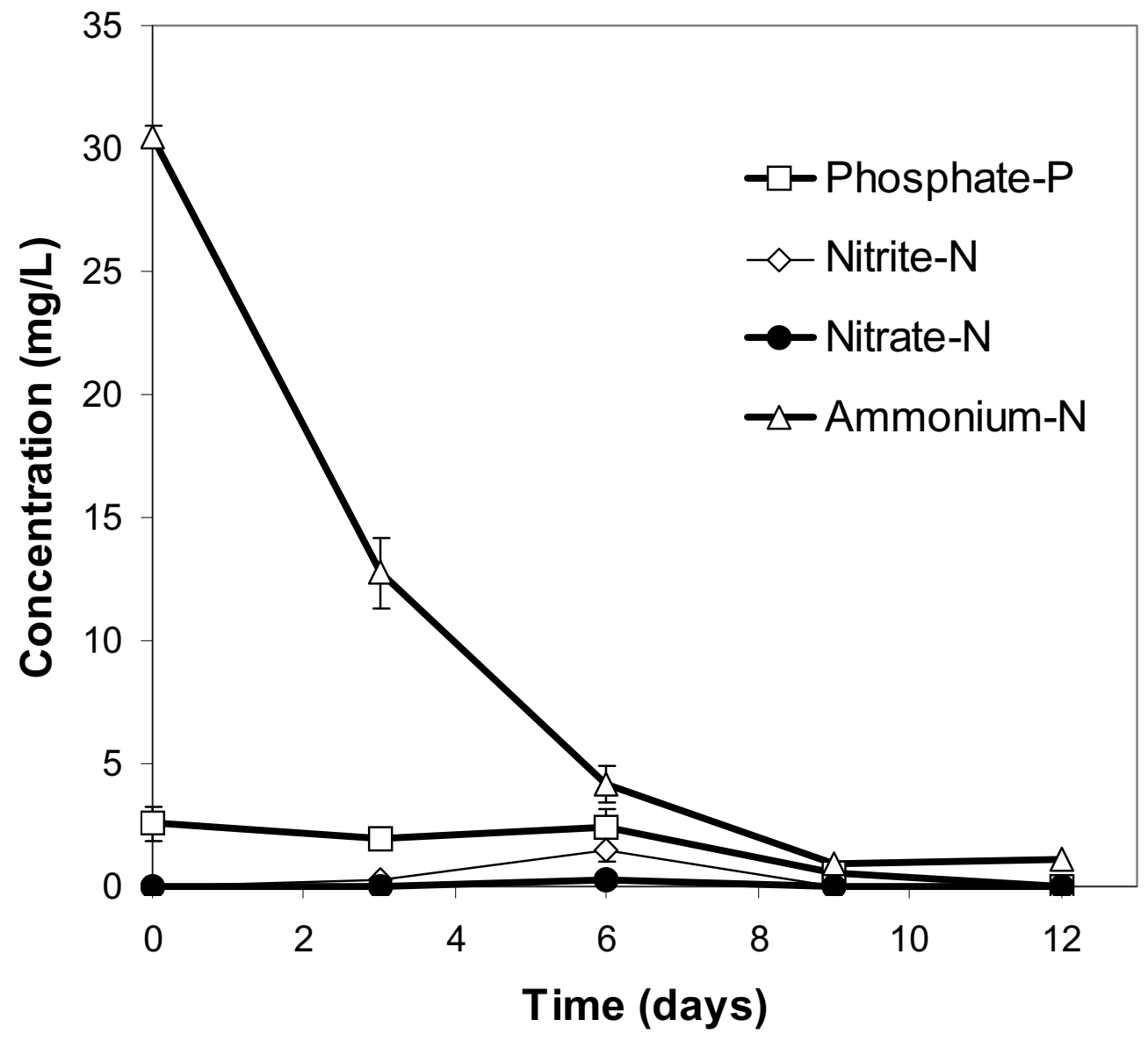

Figure 7: Nutrient removal during batch culture (triplicates) on $25 \%$ dairy wastewater. 
Table 1: Initial wastewater characteristics.

\begin{tabular}{|c|c|c|c|}
\hline \multirow[b]{2}{*}{ Wastewater characteristics } & \multicolumn{2}{|c|}{ Dairy Wastewater } & \multirow{2}{*}{$\begin{array}{c}\text { Municipal Wastewater } \\
\text { No Dilution }\end{array}$} \\
\hline & 25\% Dilution & $10 \%$ Dilution & \\
\hline $\mathrm{TSS}(\mathrm{mg} / \mathrm{L})$ & 283 & 135 & 93 \\
\hline $\operatorname{VSS}(\mathrm{mg} / \mathrm{L})$ & 220 & 120 & 58 \\
\hline $\mathrm{pH}$ & 7.9 & 7.7 & 7.2 \\
\hline Ammonium as $\mathrm{N}(\mathrm{mg} / \mathrm{L})$ & 30.5 & 16.3 & 39 \\
\hline Nitrate as $\mathrm{N}(\mathrm{mg} / \mathrm{L})$ & $<0.01$ & 0.05 & $<0.01$ \\
\hline Nitrite as $N(\mathrm{mg} / \mathrm{L})$ & $<0.01$ & 0.04 & $<0.01$ \\
\hline Organic Nitrogen $(\mathrm{mg} / \mathrm{L})$ & 50.7 & 20.2 & 12 \\
\hline TKN (mg/L) & 81.0 & 36.5 & 51 \\
\hline Total Nitrogen (mg/L) & 81.0 & 36.6 & 51 \\
\hline Phosphate as P (mg/L) & 2.6 & 1.8 & 2.1 \\
\hline
\end{tabular}


Table 2: Culture conditions in dairy wastewater experiment.

\begin{tabular}{|c|c|c|c|c|c|c|c|}
\hline \multirow[b]{2}{*}{ Day } & \multicolumn{5}{|c|}{ Air Temperature $\left({ }^{\circ} \mathrm{C}\right)$} & \multicolumn{2}{|c|}{ Avg. pH* } \\
\hline & $\begin{array}{c}\text { Insolation } \\
\left(\mathbf{W} / \mathbf{m}^{2}\right)\end{array}$ & Max & Min & Avg. & $\begin{array}{l}\text { Water Temp } \\
\text { at } 3 \mathrm{pm}\left({ }^{\circ} \mathrm{C}\right)\end{array}$ & $\begin{array}{l}10 \% \text { Dairy } \\
\text { wastewater }\end{array}$ & $\begin{array}{l}25 \% \text { Dairy } \\
\text { wastewater }\end{array}$ \\
\hline 0 & & & & & 32 & 7.7 & 7.9 \\
\hline 1 & 50 & 13.6 & 9.9 & 11.4 & 15 & 7.4 & 7.5 \\
\hline 2 & 191 & 17.3 & 7.3 & 11.3 & 30 & 7.2 & 7.1 \\
\hline 3 & 228 & 24 & 11.4 & 16.3 & 36 & 8.9 & 7.4 \\
\hline 4 & 228 & 20.9 & 7.5 & 13.1 & 35 & 9.3 & 7.6 \\
\hline 5 & 70 & 14.4 & 9.5 & 12 & 17 & 7.0 & 7.3 \\
\hline 6 & 212 & 17.9 & 10.6 & 13.1 & 32 & 6.5 & 7.1 \\
\hline 7 & 169 & 17.8 & 8.6 & 11.6 & 29 & 7.3 & 8.4 \\
\hline 8 & 226 & 15.8 & 4.5 & 9.1 & 27 & 8.6 & 9.5 \\
\hline 9 & 246 & 16.3 & 4.5 & 10.4 & 32 & 7.5 & 7.7 \\
\hline 10 & 252 & 22.3 & 4.5 & 12.9 & 37 & 6.4 & 6.4 \\
\hline 11 & 247 & 24.2 & 5.1 & 13 & 34 & 7.1 & 7.3 \\
\hline 12 & 246 & 20.9 & 5 & 11.4 & 36 & 8.3 & 8.0 \\
\hline 13 & 242 & 22.1 & 7.9 & 13.4 & 37 & & 7.3 \\
\hline 14 & 239 & 20.8 & 7.4 & 13.2 & & & \\
\hline 15 & 246 & 24.1 & 7.8 & 13.5 & & & \\
\hline
\end{tabular}

* Standard deviation of replicates ranged from 0.0 to 0.5 
Table 3: Lipid productivity of municipal wastewater cultures.

\begin{tabular}{ccccc}
\hline Sample & $\begin{array}{c}\text { VSS } \\
(\mathbf{m g} / \mathrm{L})\end{array}$ & Lipids \% & $\begin{array}{c}\text { Lipid content of } \\
\text { culture medium } \\
(\mathbf{m g} / \mathbf{L})\end{array}$ & $\begin{array}{c}\text { Lipid } \\
\text { Productivity } \\
(\mathbf{m g} / \mathbf{L} / \text { day })\end{array}$ \\
\hline $\mathbf{C O}_{2}$ 4-Day HRT & 843 & $4.9 \%$ & 41.5 & 10.4 \\
$\mathbf{C O}_{2}$ 3-Day HRT & 812 & $9.0 \%$ & 73.3 & 24.4 \\
AIR 3-Day HRT & 317 & $9.3 \%$ & 29.2 & 9.7 \\
$\mathbf{C O}_{2}$ 2-Day HRT & 412 & $11.3 \%$ & 46.2 & 23.1 \\
\hline
\end{tabular}




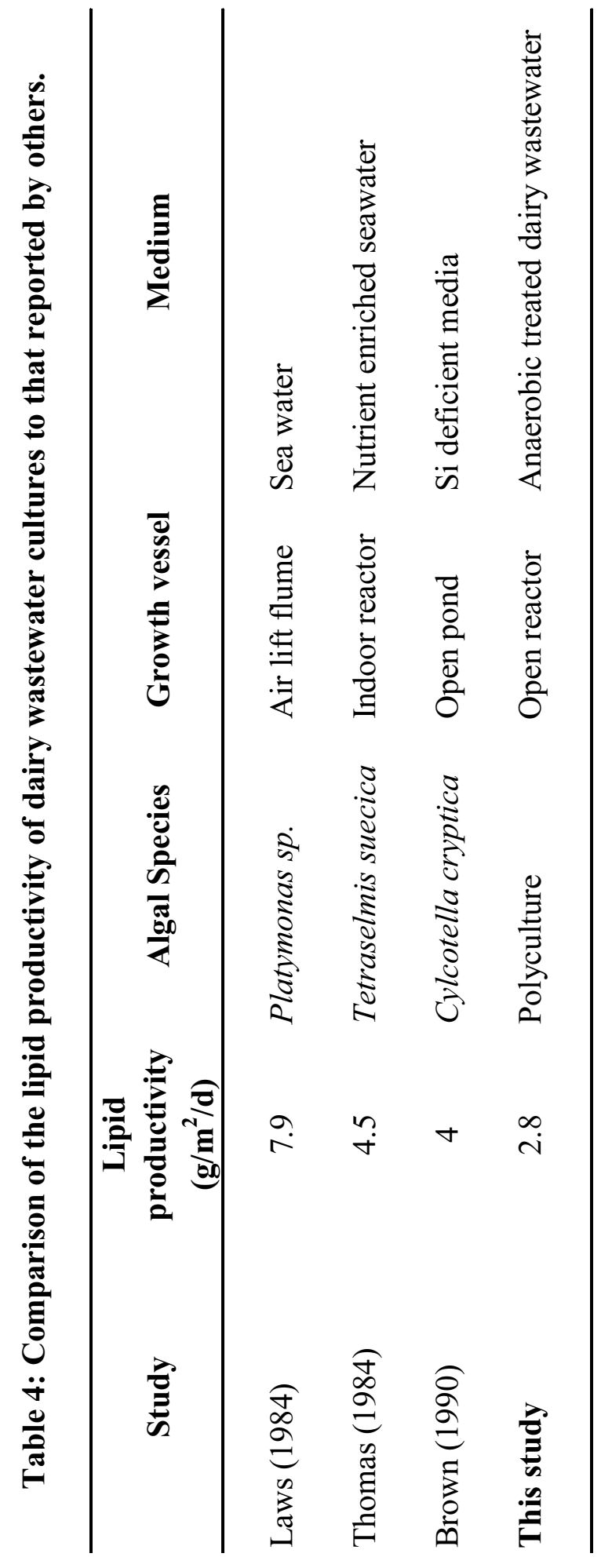


Table 5: Nutrient removal by municipal wastewater cultures.

\begin{tabular}{|c|c|c|c|}
\hline & \multicolumn{3}{|c|}{ Total Ammonia Nitrogen (mg/L) } \\
\hline & Influent & Effluent* & \% Removal \\
\hline $\mathrm{CO}_{2}$ 4-Day HRT & 39.0 & $<0.02$ & $>99 \%$ \\
\hline $\mathrm{CO}_{2}$ 3-Day HRT & 39.0 & $<0.02$ & $>99 \%$ \\
\hline Air 3-Day HRT & 39.0 & $6.1( \pm 0.89)$ & $84 \%$ \\
\hline \multirow[t]{3}{*}{$\mathrm{CO}_{2}$ 2-Day HRT } & 39.0 & $0.6( \pm 0.57)$ & $98 \%$ \\
\hline & \multicolumn{3}{|c|}{ Phosphate as $P(\mathrm{mg} / \mathrm{L})$} \\
\hline & Influent & Effluent* & \% Removal \\
\hline $\mathrm{CO}_{2}$ 4-Day HRT & 2.1 & $<0.02$ & $>99 \%$ \\
\hline $\mathrm{CO}_{2}$ 3-Day HRT & 2.1 & $<0.02$ & $>99 \%$ \\
\hline Air 3-Day HRT & 2.1 & $<0.02$ & $>99 \%$ \\
\hline $\mathrm{CO}_{2}$ 2-Day HRT & 2.1 & $0.15( \pm 0.15)$ & $93 \%$ \\
\hline
\end{tabular}

* Mean of duplicate reactors with standard deviation shown in parentheses. 
Table 6: Nutrient removal in dairy wastewater experiment at Day 15.

\begin{tabular}{|c|c|c|c|}
\hline & \multicolumn{3}{|c|}{ Total Ammonia Nitrogen (mg/L)* } \\
\hline & Influent & Effluent & \% Removal \\
\hline 25\% Dilution & $30.5( \pm 0.4)$ & $1.1( \pm 0.1)$ & $96 \%$ \\
\hline \multirow[t]{3}{*}{ 10\% Dilution } & $16.3( \pm 4.8)$ & $0.6( \pm 0.1)$ & $96 \%$ \\
\hline & \multicolumn{3}{|c|}{ Phosphate as $\mathbf{P}(\mathrm{mg} / \mathrm{L}) *$} \\
\hline & Influent & Effluent & \% Removal \\
\hline 25\% Dilution & $2.6( \pm 0.7)$ & $<0.02$ & $>99 \%$ \\
\hline 10\% Dilution & $1.8( \pm 0.01)$ & $<0.02$ & $>99 \%$ \\
\hline
\end{tabular}

* Average of triplicate reactors (standard deviation, $\mathrm{n}=3$ ) 
Table 7: Comparison of total ammonia nitrogen removal to that reported for other algae treatment systems.

\begin{tabular}{lcll}
\hline \multicolumn{1}{c}{ Study } & $\begin{array}{c}\text { \% Total } \\
\text { Ammonia-N } \\
\text { Removal }\end{array}$ & \multicolumn{1}{c}{ Algae Species } & \multicolumn{1}{c}{ Medium } \\
\hline Martinez et al. (2000) & $80-99$ & Scenedemus obliques & Autoclaved municipal wastewater \\
Lincoln et al. (1996) & 99 & Arthrouspira plantensis & Anaerobically treated dairy wastewater \\
Green et al. (1995) & 99 & Polyculture & Municipal wastewater \\
This study & 99 & Polyculture & Municipal wastewater \\
This study & 96 & Polyculture & Anaerobically treated dairy wastewater \\
\hline
\end{tabular}

